\title{
Fetomaternal outcome in severe preeclampsia and eclampsia: a retrospective study in a tertiary care centre
}

\author{
Shobha S. Pillai* \\ Department of Obstetrics and Gynecology, Government Medical College Ernakulam, Kochi, Kerala, India \\ Received: 25 June 2017 \\ Accepted: 25 July 2017 \\ *Correspondence: \\ Dr. Shobha S. Pillai, \\ E-mail:dr.shobhapillai@gmail.com \\ Copyright: () the author(s), publisher and licensee Medip Academy. This is an open-access article distributed under \\ the terms of the Creative Commons Attribution Non-Commercial License, which permits unrestricted non-commercial \\ use, distribution, and reproduction in any medium, provided the original work is properly cited.
}

\begin{abstract}
Background: Hypertensive disorders of pregnancy are a leading cause of maternal and perinatal mortality and morbidity worldwide. In India, they account for the third most important cause of maternal mortality. The objectives of this study were to evaluate maternal and perinatal outcome and complications in cases with severe preeclampsia and eclampsia.

Methods: A retrospective study was carried out on 110 women with severe preeclampsia and eclampsia in a tertiary care referral centre over a period of 15 months. Only those cases with initial B.P reading of $\geq 160 / 110 \mathrm{~mm} \mathrm{Hg}$ or presenting with eclampsia were included in the study. Investigations and management were carried out as per standardized department protocol and maternal and fetal outcomes were analyzed.

Results: $42 \%$ of the cases were in the age group of 26-30 years, nearly $61 \%$ were primigravidae and the majority (64) were referred from peripheral hospitals. Liver function tests were deranged in $19 \%$ of the patients and $17 \%$ had abnormal renal function. Nifedipine was the most commonly used antihypertensive and magnesium sulphate was the anticonvulsant used in all the cases. Lower segment caesarean section was the mode of delivery in $64.5 \%$ of the cases. Commonest maternal complication was atonic PPH. There was no maternal mortality but there were 3 maternal near-miss cases due to DIC. $65 \%$ of the cases had a preterm delivery and $39 \%$ of the babies needed NICU admission. There were 10 neonatal deaths.

Conclusions: Accessible health care and health education and awareness regarding antenatal check-ups for all women will lead to early detection of severe preeclampsia. Prompt treatment and management of its complications will certainly improve the maternal and fetal outcome.
\end{abstract}

Keywords: Eclampsia, Maternal morbidity, Maternal mortality, Perinatal morbidity, Perinatal mortality, Preeclampsia

\section{INTRODUCTION}

Hypertensive disorders complicate about $10 \%$ of all pregnancies worldwide. Hypertension, along with haemorrhage and infection form a deadly triad accounting for a major share of maternal morbidity and mortality. ${ }^{1}$ The World Health Organisation systematically reviews maternal mortality worldwide and in developed countries $16 \%$ of maternal deaths were reported to be due to hypertensive disorders. ${ }^{2}$ In India hypertensive disorders account for the third most important cause of maternal mortality. ${ }^{3}$

For classifying and defining hypertensive disorders of pregnancy, The National High Blood Pressure Education Program (NHBPEP) and ACOG (2013 b) evidence based recommendations have been taken into consideration. ${ }^{4}$ 
Preeclampsia is a multisystem, multifactorial disease defined as Blood Pressure (B.P) reading of $\geq 140 / 90 \mathrm{~mm}$ $\mathrm{Hg}$ on two occasions 4 hours apart and $>0.3 \mathrm{~g}$ protein in 24 hour urine specimen after 20 weeks of gestation in a previously normotensive woman. Severe Preeclampsia is B.P reading of $\geq 160 / 110 \mathrm{~mm} \mathrm{Hg}$ and $>5 \mathrm{~g}$ protein in 24 hour urine specimen or symptoms of end organ damage like deranged LFT, thrombocytopenia, oliguria, visual disturbances, pulmonary oedema etc. Eclampsia is defined as generalised tonic clonic seizures and /or unexplained coma in a woman with preeclampsia.

In spite of advances in medicine, preeclampsia and eclampsia continue to remain leading causes of maternal and perinatal mortality and morbidity throughout the world. Severe Preeclampsia can lead to multiple lifethreatening complications like eclampsia, cerebral haemorrhage, cardiovascular complications, hepatic failure, acute renal failure, pulmonary oedema, ARDS (Adult Respiratory Distress syndrome), DIC (Disseminated Intravascular Coagulation) HELLP syndrome (Haemolysis, Elevated Liver enzymes, Low Platelet), retinal detachment, cortical blindness, hypoxic cerebral damage and even maternal death.

Fetal complications are mainly due to uteroplacental insufficiency leading to IUGR (Intrauterine Growth Restriction), low birth weight babies, IUFD (Intrauterine Fetal death) and complications due to prematurity. There are still no widely accepted biochemical markers for early detection of Preeclampsia but some maternal and pregnancy characteristics have been identified as risk factors, these are nulliparity, previous history of preeclampsia, maternal age over 40, multiple gestation, molar pregnancy, pregestational diabetes, vascular, endothelial or renal diseases, maternal smoking, obesity and certain genetic factors. ${ }^{5}$

Various biological, biochemical and biophysical markers implicated in preeclampsia syndrome have been studied as markers to predict the development of preeclampsia. Uterine artery doppler velocimetry in the late first and second trimesters showing increased resistance may be a predictive test for the development of preeclampsia. ${ }^{5,6}$ Currently no other test is reliable, valid or economical and most have met with poor sensitivity and poor positive predictive value.

Various strategies used to prevent or modify the severity of preeclampsia have been evaluated, but none of them have been found to be convincing or reproducible. ${ }^{1}$

Maternal and perinatal mortality and morbidity due to preeclampsia can only be prevented by access to quality antenatal care, early diagnosis and recognition of risk factors, careful monitoring and timely interventions.

The present study was undertaken in a tertiary care referral hospital in South India with the aim of evaluating the maternal and perinatal outcome and complications of severe preeclampsia and eclampsia.

\section{METHODS}

This research is a 15 month retrospective study of severe preeclampsia and eclampsia cases in Government medical College, Ernakulam, Kerala from March 2014 to July 2015. A total of 110 women with severe preeclampsia and eclampsia were included in the study and their case records were retrospectively analysed.

\section{Inclusion criteria}

B.P reading of $\geq 160 / 110 \mathrm{mmHg}$ with $1+$ or more albuminuria was the criteria followed for categorising severe preeclampsia. Eclampsia was presence of seizures in women with preeclampsia which could not be attributed to other causes.

\section{Exclusion criteria}

Patients with chronic hypertension (before 20 weeks of gestation), chronic renal disease, connective tissue disorders and mild preeclampsia were not included in the study.

A Pro Forma was used to record information on maternal age, parity, booking status, gestational age at diagnosis mode of delivery, treatment given, complications - both maternal and fetal and finally the maternal and fetal outcome.

Investigations and management were carried out in accordance with the standardised department protocol. Investigations that were routinely done for all the cases were complete haemogram, platelet count, liver function tests, renal function tests, coagulation profile, 24 hour urine protein. Ultrasonography with doppler was done after stabilising the condition of the patients in selected cases.

Antihypertensive drugs used were alphamethyldopa, nifedipine and labetalol - both orally and parenterally, singly or in combination as needed. Magnesium sulphate was the anticonvulsant of choice used both as prophylaxis and treatment according to the Pritchard's regime. Preterm delivery was defined as delivery before 37 weeks of gestation. Neonatal morbidity was estimated by number of newborns needing NICU admission. The data was compiled and analysed.

\section{RESULTS}

Out of the 110 patients in the present study, preeclampsia was observed in different age groups ranging from 18 to 41 , maximum number of cases 47 were in the age group of 26 to 30 years. There were 8 patients over the age of 35. Table I gives the distribution cases vis a vis age of patients. 
Table 1: Distribution of cases according to the age of the patients.

\begin{tabular}{|lll|}
\hline Age & No. of cases & $\%$ \\
\hline$<20$ & 18 & 16.36 \\
\hline $21-35$ & 27 & 24.54 \\
\hline $26-30$ & 47 & 42.12 \\
\hline $31-35$ & 10 & 9.09 \\
\hline$>35$ & 8 & 7.27 \\
\hline
\end{tabular}

Table 2: Distribution of cases according to their obstetric status.

\begin{tabular}{|lll|}
\hline Gravidity & No. of cases & $\%$ \\
\hline Primigravida & 67 & 60.90 \\
\hline Multigravida & 43 & 39.10 \\
\hline
\end{tabular}

Table 3: Distribution of cases according to their antenatal registration status.

\begin{tabular}{|lll|}
\hline Registration status & No. of cases & $\%$ \\
\hline Booked & 86 & 78.18 \\
\hline Unbooked & 24 & 21.81 \\
\hline
\end{tabular}

This study was carried out in Kerala, where antenatal coverage is very good and so only $21.81 \%$ of our patients were unbooked. Out of the total 110 cases, 64 were referred from peripheral hospitals.

Table 4: Distribution of cases according to the investigations done.

\begin{tabular}{|c|c|c|c|c|}
\hline Proteinuria & $\leq+1$ & $\geq+2$ & $\geq+3$ & \\
\hline Cases & 15 & 31 & 64 & \\
\hline$\%$ & 13.63 & 28.18 & 58.18 & \\
\hline LFT & $\begin{array}{l}\text { SGOT } \\
>70 \\
\text { IU/L }\end{array}$ & $\begin{array}{l}\text { SGPT } \\
>70 \\
\text { IU/L }\end{array}$ & $\begin{array}{l}\mathrm{LDH} \\
>600\end{array}$ & $\begin{array}{l}\text { Serum } \\
\text { bilirubin } \\
>1.2 \\
\mathrm{mg} / \mathrm{dl}\end{array}$ \\
\hline Cases & 21 & 21 & 15 & 16 \\
\hline$\%$ & 19.09 & 19.09 & 13.63 & 14.54 \\
\hline RFT & $\begin{array}{l}\text { Blood } \\
\text { urea } \\
>40\end{array}$ & $\begin{array}{l}\text { Serum } \\
\text { creatinine } \\
>0.8\end{array}$ & $\begin{array}{l}\text { Serum } \\
\text { uric acid } \\
>7\end{array}$ & \\
\hline Cases & 15 & 17 & 17 & \\
\hline$\%$ & 13.63 & 15.45 & 15.45 & \\
\hline $\begin{array}{l}\text { Coagulation } \\
\text { profile }\end{array}$ & $\begin{array}{l}\text { Platelet } \\
\text { count } \\
<1 \text { lakh }\end{array}$ & $\begin{array}{l}\text { Deranged } \\
\text { PT INR }\end{array}$ & $\begin{array}{l}\text { Peripheral } \\
\text { smear with } \\
\text { haemolysis }\end{array}$ & \\
\hline Cases & 16 & 18 & 8 & \\
\hline$\%$ & 14.54 & 16.36 & 7.27 & \\
\hline
\end{tabular}

$58 \%$ of the patients had $\geq+3$ proteinuria, $17 \%$ had abnormal renal function tests. Liver enzymes were elevated in $19 \%$ and $7 \%$ patients showed evidence of haemolysis on peripheral smear.

It was observed that the majority $44(40 \%)$ of the patients presented at gestational age between 33 to 36 weeks.
Extreme preterm presentation before 28 weeks of gestation was noted in $13(11.81 \%)$.

Table 5: Gestational age at presentation.

\begin{tabular}{|lll|}
\hline Gestational age & No. of cases & $\%$ \\
\hline$\leq 28$ weeks & 13 & 11.81 \\
\hline $29-32$ weeks & 15 & 13.63 \\
\hline $33-36$ weeks & 44 & 40.0 \\
\hline$\geq 37$ weeks & 38 & 34.54 \\
\hline
\end{tabular}

Table 6: Antihypertensives drugs used in the management.

\begin{tabular}{|lll|}
\hline Drug used & No. of cases & $\%$ \\
\hline Nifedipine & 43 & 39.09 \\
\hline Labetalol & 31 & 28.18 \\
\hline Nifedipine+Alphamethyldopa & 9 & 8.18 \\
\hline Nifedipine+Labetalol & 27 & 24.54 \\
\hline
\end{tabular}

Nifedipine was the most commonly used drug in the present study, either singly or in combination. Alphamethyldopa was used when patients presented with severe preeclampsia before 28 weeks of gestation, but in all the cases it was used in combination with nifedipine. Labetalol was used singly as well as in combination with nifedipine.

Table 7: Mode of delivery.

\begin{tabular}{|lll} 
Mode of delivery & No. of cases & $\%$ \\
\hline Normal vaginal delivery & 31 & 28.18 \\
\hline LSCS & 71 & 64.54 \\
\hline Instrumental & 5 & 4.54 \\
\hline Hysterotomy & 3 & 2.72 \\
\hline
\end{tabular}

Table 8: Indications for caesarean section.

\begin{tabular}{|lll|}
\hline Indication & No. of cases & $\%$ \\
\hline Previous caesarean section & 40 & 36.36 \\
\hline Non-reassuring fetal status & 12 & 10.90 \\
\hline Failed induction & 16 & 14.54 \\
\hline CPD, contracted pelvis & 6 & 5.45 \\
\hline $\begin{array}{l}\text { Doppler abnormalities, } \\
\text { IUGR, oligohydramnios }\end{array}$ & 12 & 10.90 \\
\hline Abruption & 4 & 3.63 \\
\hline
\end{tabular}

Previous caesarean section was the commonest indication for caesarean section as these patients presenting with severe preeclampsia or eclampsia were not given trial of labour and repeat caesarean was done after stabilising the patient. In some cases, there was an overlap of Indications like doppler abnormalities along with failed induction and abruption with non-reassuring fetal status.

Atonic PPH was the commonest complication in 26 patients and it was managed with oxytocin and prostaglandin F2 alpha. Bilateral uterine and ovarian artery ligation was needed in 12 cases. 
Table 9: Maternal complications and outcome.

\begin{tabular}{|lll|}
\hline Complication & No. of cases & $\%$ \\
\hline Eclampsia & 13 & 11.81 \\
\hline Abruptio placentae & 8 & 7.27 \\
\hline Partial HELLP & 21 & 19.09 \\
\hline HELLP & 5 & 4.54 \\
\hline PPH & 26 & 23.63 \\
\hline DIC & 3 & 2.72 \\
\hline Pulmonary edema & 1 & 0.90 \\
\hline Renal dysfunction & 8 & 7.27 \\
\hline ARDS & 0 & 0 \\
\hline
\end{tabular}

There were 13 cases of eclampsia in the study- 10 antepartum and 3 postpartum. All the 13 cases were treated with magnesium sulphate. Out of the 110 patients, 66 received prophylactic magnesium sulphate. Partial HELLP syndrome was noted in 21 patients. Near- miss cases were there in 3 cases with DIC and 5 cases of HELLP. These near-miss cases were managed by a multidisciplinary team. There was no maternal mortality.

Table 10: Perinatal complications and outcome.

\begin{tabular}{|lll|}
\hline Complication & No. of cases & $\%$ \\
\hline IUGR & 24 & 21.81 \\
\hline Prematurity & 71 & 64.54 \\
\hline Respiratory distress syndrome & 25 & 22.72 \\
\hline Meconium aspiration & 5 & 4.54 \\
\hline Intrauterine death & 7 & 6.36 \\
\hline Still birth & 3 & 2.72 \\
\hline NICU admission & 43 & 39.09 \\
\hline Low birth weight babies & 37 & 33.63 \\
\hline Neonatal death & 10 & 9.09 \\
\hline
\end{tabular}

The number of cases of preterm delivery were quite high at $65 \%$ due to the premature induction of labour in cases of severe preeclampsia and eclampsia. NICU admission was needed for 43 babies, 25 had respiratory distress syndrome. In present study, there were 10 neonatal deaths.

\section{DISCUSSION}

Out of the 110 cases of severe preeclampsia and eclampsia in the present study, 67 were primigravidae and 18 were less than 20 years of age. The highest number of cases were in the age group of 26-30 years. Severe preeclampsia was seen more commonly in primigravidae. Other studies notably by Sibai and Cunningham also support this view. ${ }^{7}$ Nulliparity as a separate risk factor for severe preeclampsia has been reported in studies by Saxena et al in India and by CondeAgudelo in Latin American women. 8

About $75 \%$ of the cases presented at gestational age $>33$ weeks. Singhal et al also reported similar findings. ${ }^{10}$ Unlike other studies, in the present study, $78 \%$ were booked cases, but $58 \%$ of cases were referred from peripheral hospitals. The incidence of severe preeclampsia and eclampsia are higher among unbooked patients. In a study from rural Gujarat by Gandhi et al $72.6 \%$ of total cases of preeclampsia were unbooked patients. ${ }^{11}$

The most common mode of delivery was lower segment caesarean section in $64.5 \%$ of the cases and the most common indication was previous one or more caesarean sections. The mode of delivery was determined by severity of maternal condition, Bishop's score, gestational age, fetal condition, USG and laboratory investigations. Singhal et al reported $33 \%$ caesarean section rate. 10 Tufnell et al reported as high as $72 \%$ caesarean section rate in BJOG. ${ }^{12}$ Caesarean section rates of $71 \%$ and $78 \%$ respectively were reported by Miguel $\mathrm{M}$ et al and Dissanayake $\mathrm{VH}$ et al. ${ }^{13,14}$ The high rate of caesarean section in the present study is due to more than $36 \%$ cases being previous caesarean section and also due to emergency delivery approach taken to prevent further maternal and fetal complications due to severe preeclampsia or eclampsia especially in cases where the cervix is unfavourable for induction.

$10.9 \%$ of cases had LSCS for reversed or absent end diastolic flow in umbilical artery. Uteroplacental insufficiency seen in severe preeclampsia and eclampsia is the major cause of IUGR seen in $21.8 \%$ of the cases in the present study. Prematurity was the most common complication among the neonates seen in $64.5 \%$ of the cases. Tufnell et al reported $65.3 \%$ incidence of prematurity. ${ }^{11}$ The high incidence of preterm delivery could be attributed to the early intervention and induction of labour or LSCS done to avert further maternal and perinatal complications.

Main factors affecting perinatal mortality and morbidity were prematurity, IUGR and irregular antenatal visits. Being a tertiary care centre we have an efficient team of neonatologists and neonatal intensive care unit (NICU) back up. The perinatal mortality rate in our study was 18 $\%$ i.e. 20 in number of which 7 were intrauterine fetal deaths 3 stillbirths and 10 neonatal deaths all due to prematurity and respiratory distress syndrome. A perinatal mortality rate of $22.7 \%$ was reported from south-east Nigeria and Shahin et al from Pakistan reported perinatal mortality of $41.6 \% .^{15,16}$

The main factors determining maternal morbidity are associated risk factors like diabetes, anaemia, nulliparity, advanced maternal age, early onset preeclampsia, severe preeclampsia and previous history of preeclampsia. In this study, postpartum haemorrhage was the most common maternal complication seen in $23.6 \%$ of cases followed by partial HELLP in $19.09 \%$ cases and eclampsia in $11.81 \%$ cases. Various studies have reported abruptio placenta and HELLP syndrome as more common complications. A study by Farid $\mathrm{M}$ et al had $11 \%$ incidence of HELLP syndrome and $10 \%$ incidence of abruptio placenta. ${ }^{17}$ In a ten year study done by 
Igberase et al the important causes of maternal mortality in severe preeclampsia were acute renal failure, disseminated intravascular coagulopathy (DIC), cardiac arrest, pulmonary edema and cerebrovascular accidents. ${ }^{18}$ In the present study, there was no maternal mortality, however there were 3 maternal near-miss cases due to DIC and 5 cases of HELLP syndrome. These were managed in the intensive care unit of the hospital by a multidisciplinary team.

\section{CONCLUSION}

Preeclampsia and eclampsia continue to be significant causes of maternal and fetal morbidity and mortality. Though prevention is not possible, it is important to recognise early warning symptoms and signs so that life threatening complications can be averted. Provision of quality antenatal health care services, increasing patient awareness about warning symptoms, investigations, timely delivery and intensive monitoring in the intrapartum and postpartum period have the potential to improve maternal and perinatal outcome. Education and empowerment of women and accessible health care especially to the socioeconomically deprived and rural population is the need of the hour.

\section{ACKNOWLEDGMENTS}

Authors sincerely acknowledge the support received from the Principal, faculty and administration of Government Medical College Ernakulam for carrying out the research work.

\section{Funding: No funding sources}

Conflict of interest: None declared

Ethical approval: The study was approved by the Institutional Ethics Committee

\section{REFERENCES}

1. Cunningham FG, Leveno KJ, Bloom SL, Hauth JC, Rouse DJ, Catherine YS. Williams Obstetrics. $24^{\text {th }}$ Ed. New York, NY: McGraw Hill Companies;2014.

2. Khan KS, Wojdyla D, Say L, Gulmezoglu AM, Van Look PF. WHO analysis of causes of maternal death: a systematic review. Lancet. 2006;367:1066-74.

3. Govt. of India (Sample Registration System) Maternal mortality in India, 1997-2003. Trends, causes and risk factors. Registrar General of India, New Delhi in collaboration with Centre for Global Health Research, Toronto.

4. Hypertension in pregnancy report of the American College of Obstetricians and Gynecologists' task force on hypertension in pregnancy. [Executive Summary]. ACOG. 2013;122(5):1122-31.

5. Conde-Agudelo A, Villar J, Lindeheimer M. World Health Organization systematic review of screening tests for preeclampsia. Obstet Gynecol. 2004;104(6):1367-91.

6. Meler E, Figueras F, Bennasar M, Gomez O, Crispi F, Gratacos E. The prognostic role of uterine artery Doppler investigation in patients with severe early onset preeclampsia. Am J Obstet Gynecol. 2010;202(6):559.e1-e4.

7. Sibai BM, Cunningham FG. Prevention of preeclampsia and eclampsia. In: Lindheimer MD, Roberts JM, Cunningham FG, editors. Chesley's Hypertensive Disorders of Pregnancy. $3^{\text {rd }}$ Ed. New York: Elsevier; 2009:215.

8. Saxena S, Srivastava PC, Thimmaraju KV, Mallick AK, Dalmia K, Das B. Socio-demographic profile of pregnancy induced hypertension in a tertiary care centre. Sch J Appl Med Sci. 2014;2:3081-6.

9. Conde-Agudelo A, Belizán JM. Risk factors for preeclampsia in a large cohort of Latin American and Caribbean women. BJOG. 2000;107:75-83.

10. Singhal S, Deepika, Anshu, Nanda S. Maternal and perinatal outcome in severe pre-eclampsia and eclampsia. South Asian Federation Obstet Gynecol. 2009;1(3):25-8.

11. Gandhi MR, Jani PS, Patel UM, Kakani CR, Thakor NC, Gupta N. Perinatal outcome in pregnancy induced hypertension cases at GMERS Medical College, Dharpur-Patan, North Gujarat region, India: a prospective study. Int J Adv Med. 2015;2:152-5.

12. Tufnell DJ, Jankowicz D, Lindow SW, Lyons G, Mason GC, Russell IF, et al. Outcome of severe preeclampsia/eclampsia. Yorkshire 1999/2003. Br J Obstet Gynecol. 2005;112:875-80.

13. Miguil M, Chekairi A. Eclampsia, study of 342 cases. Hypertens Pregnancy. 2008;27(2):103-11.

14. Dissanayake VH, Samarasinghe HD, Morgan L, Jayasekara RW, Seneviratne HR, Pipkin FB. Morbidity and mortality associated with preeclampsia at two tertiary care hospitals in Sri Lanka. J Obstet Gynaecol Res. 2007;33(1):56-62.

15. Ajah LO, Ozonu NC, Ezeonu PO, Lawani LO, Obuna JA, Onwe EO. The feto-maternal outcome of preeclampsia with severe features and eclampsia in Abakaliki, South-East Nigeria. J Clin Diagn Res. 2016;10(9):QC1-QC21.

16. Shaheen B, Hassan L, Obaid M. Eclampsia, a major cause of maternal and perinatal mortality: a prospective analysis at a tertiary care hospital of Peshawar. J Pak Med Assoc. 2003;53(8):346-50.

17. Mattar F, Sibai BM. Risk factors for maternal morbidity. Am J Obstet Gynecol. 2000;182:307-12.

18. Igberase GO, Ebeigbe PN. Eclampsia: ten-years of experience in a rural tertiary hospital in the Niger delta, Nigeria. J Obstet Gynecol. 2006; 26(5):414-7.

Cite this article as: Pillai SS. Fetomaternal outcome in severe preeclampsia and eclampsia: a retrospective study in a tertiary care centre. Int J Reprod Contracept Obstet Gynecol 2017;6:3937-41. 